\title{
AFROCENTRISM OR EUROCENTRISM: THE DILEMMA OF AFRICAN DEVELOPMENT
}

\section{J. Chidozie Chukwuokolo}

\section{Introduction}

Africa has not remained the same since the rape of its continent by the West who pretended to be on a "civilizing mission". There was a total distortion of all the values of the African to the advantage of the West. For over two centuries now Africa is not certain as to the path of civilization to follow: Afrocentric or Eurocentric?

This became worse as the invaders have dictated the politico-socio-economic trend in the whole world. The index in measuring world development is based on the triad concepts of politics, sociology and economics. Hence, various terminologies have arisen to delineate levels of development namely; developed, undeveloped, developing, first world, etc. The so called developing or third world countries have tasted several passing phases in the European socio-economic and political experimentations with them. This has led to changing perceptions and attitudes. Martin Khor states the reasons for this thus:

The reason for the changing perception of and attitude towards globalization are many. Among the important factors are the lack of tangible benefits to developing countries from opening their economies, despite the well publicized claims of export and income gains; the economic losses and social dislocation that are being caused to many developing countries by rapid financial and trade liberalization; the growing inequalities of wealth and opportunities arising from globalization; and the perception that environmental, social and cultural problems have been made worse by the working of the global free market economy ${ }^{1}$.

This apparent lack of benefit from the passing phases of European experimentation with developing countries dominates the Afrocentic circles especially as globalization is the latest stage of imperialism. Certain questions are raised; what is actually meant by 
development? In the face of competing choices as to which path to toe - African or European- which is the rightful or best alternative for Africa if it wants to develop? What should guide African choices? Should it continue to trail behind Europe and their valuebase on the evolution of society?

The purpose of this paper is to address the above questions with the view to recommending the best path to toe for African development. However, so many postulations have been made by scholars as panacea to African under-development. Most of them toe the line of exclusionism or boycott. The real impact of Afrocentrism and Eurocentrism is not fully understood. This lacuna as to what should constitute the nature and mechanism of the impact of the value base of these opposing development plans is what this paper intends to address.

\section{Diachronic Analysis of Development}

Development has many construals. For us to appreciate this term properly, we have to survey the construals as they appeared over the years both in theory and in practice. Agbakoba sees development as a process by which humans seek to maximize the realization of themselves. This is in line with Mabogunje's conceptualization: 'Development is essentially a human issue, a concern with the capacity of individuals, to realize their inherent potentials and effectively to cope with the changing circumstances of their lives ${ }^{2}$

To clarify the notion of self-realization leads Agbakoba delineates development as universal and particular. 'The universal dimensions of self-realization consists of those values, orientations, attitudes, ideas, practices and objects which are necessary (either as preconditions or as enhancing conditions) for the realization of people across the globe' ${ }^{3}$.

He notes that the particular aspects of development are those that concern specific communities and individuals. His critical analysis brought to light that every society, based on its historical, cultural and geographical antecedents and conditions formulates its communal values and aesthetic sense in respect of secondary needs.

However, development at this level is characterized as a mere process without showcasing the movement process of 
development. In the 1950s up till 1980s, development was conceived in terms of one of the triad. This was measurable in terms of the level of industrialization, technological prowess and Gross National Productivity. Rogers captures this notion most succinctly when he wrote that development was "a type of social change in which new ideas are introduced to produce higher per capita income and levels of living, through more modern production methods and improved social organization",

Development was conceived basically in this construal such that capitalist west was seen as a model. This view led the third world into conceiving development in terms of replication or imitation of Europe. This wrong concept of development was responsible for the state of Africa since development was construed as a transfer of European economic and technological prowess into Africa.

Unfortunately the impacts of the universalistic conception of development were different in Europe as they had a nodal organizing principle of development. This differing effect base led to the lack of a universal conception of development in Africa. The need for a broader conception of development became imperative. Samir Amin for instance argues that development is principally about reaching modernity encapsulated by a secular worldview. This includes freedom of individuals in making their own histories, both as individuals and as communities within the purview of democracy. This means the conferment on individuals the ability to challenge and break with tradition.

Diagne's conception of development emphasis the exploration of the future as a "prospective" in time as it relates to the problem of African development. Keita captures this position.

First Diagne critically evaluates and finds wanting the theories of time in the African sociological context as formulated by John Mbiti and French colonial theorist Levy-Bruhl. Diagne argues against Mbiti's notion that time in the African context is not intrinsically future oriented with reference to the different plans and programmes for African development, such as the Lagos plan of Action and the present NEPAD, Diagne attempts to show how the idea of time as it applies to 
prospective and a developmental political culture could produce for the youth of Africa a vision of tomorrow with a future in Africa and not elsewhere. ${ }^{5}$

Gordon approaches development from the Fanonian stance. Gordon's survey of Fanon's two classic works The Wretched of the Earth and Black Skin, White Mask, lays emphasis on the cardinal aspects of colonialism and neo-colonialism: the psychological dimension which determines the political and economic worldview of the African leadership. Gordon opines that the logical result of western normativity vis-a-vis under-development is the creation of what he called "problem people." For him, the crux of the matter for the "problem people" is how to be actional. Gordon further invokes Wynters critique that development theory is a symptom of western narcissism. Gordon finally formulates a theory of development he terms postcolonial phenomenology. This is simply the idea that development requires an existential and actional output.

Messay Kebede opines that development in Africa should be conceived in terms of the prior decolonlization of the African mind. Hountondji's conception is a radical observation of the dependent and marginalized relationship between intellectual research in Africa and that of Europe as needing separation if actual development has to be met for the African.

Nyamnjoh takes the problems of development in terms of the alienating education forced on Africans via colonialism. For him, European education is a concourse of empiricist and materialist epistemology. His solution is a paradigm change in educational orientation of the African.

Keita's attempt is holistic. Africa is conventionally believed to be a special case study for development plans as it has never attempted to develop. But his standpoint is a recast of antique history of Africa as the cradle of civilization. Though this condition changed about five centuries ago, he sets for an evaluation of what the development contour for Africa should look like economically and politically. Ultimately Keita opines that it is only when the discourse is predominantly African within the context of theories in African universities and research centers that maximal and concerted progress will be attained. Hence he argues: 
Critical analysis of the idea of development reveals that development entails not just economic ministrations about alleviating poverty but also psycho-socio- logical analysis in the form of the examination of mental structures, beliefs, and attitudes conditioned by the colonial experience, sociological analysis in the form of examining the role that religion plays in facilitating or retarding development, and historical analysis in the form of evaluating the historical contingency of economic, political, and sociological ideas of Western provenance that are now viewed as universal and necessary for development. An examination of role of the concept of time in Africa's pre-colonial sociology also demonstrates that the essentialist and qualitatively different notions of time attributed to Africa cannot be supported and hence play no role in formulating dynamically prospective theories of development ${ }^{6 .}$

Our efforts so far have been to show that the concept of development is a complex and difficult one to realize. This is because any attempt to define development in a non holistic sense will result in overemphasis on an aspect of development as seen in those that reduced development in terms of economics. Development is therefore, a holistic evolution of all the aspects of the society, namely politically, socially, psychologically, religiously, intellectually technologically, scientifically and culturally for the advancement of the society as a whole as an aggregate of individuals. At the base of our discussions are the notions of two radically opposed paradigms: Afrocentric and Eurocentric ideas. Since, development has to be taken holistically; we think that rational choices have to be taken holistically if Africa is to move ahead. Therefore, none of the two paradigms has any moral right to appropriate to itself the panacea to African under-development.

\section{Eurocentrism and Development in Africa}

The dialectical inter-phase that occurred during European colonization left Africa and its diaspora wrecked psychologically, economically, culturally, politically and otherwise. In effect, this 
period saw Africa under colonial bondage, involving socio- political domination, slavery and economic exploitation, racial and cultural devastation. In fact, the colonizers destroyed the philosophical and religious base of Africa and foisted European system as alternative. Colonial experience left two broad "legacies" on Africa: denial of African identity and the foisting of western thought and cultural realities and perspectives on Africans.

The European colonialists found it difficult to believe that a group of people raped and devastated by them could own the ancestry of letters and civilization that they share in. Historians, ethnographers and philosophers were therefore recruited to do the ignoble job of distorting historical facts. Hugh Trevor Roper's antiintellectual stance captures this atmosphere:

It is fashionable to speak today as if European History were devalued: as if historians in the past, have paid too much attention to it, and as if nowadays; we should pay less. Undergraduates seduced as always by the changing breath of journalistic fashion, demand that they should be taught the history of black Africa. Perhaps, in the future, there will be some African history to teach. But at present there is none or very little: there is only the history of the Europeans in Africa. The rest is largely darkness, like the history of pre-European pre-Columbian America. And darkness is not a subject for history. ${ }^{7}$

Other highly revered western scholars added credence to this ignoble enterprise. Hegel opines that Africa only hears the echo of the majestic march of world civilization across Europe and through which the absolute spirit fulfills and realizes itself.

He avers that a nation without a metaphysical view is like a temple richly ornamented in many respects but without its holy of

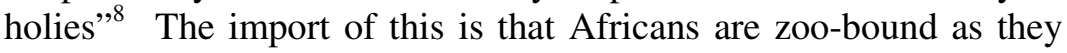
lack philosophy which is mankind's greatest intellectual achievement. David Hume was no less a hireling of Eurocentrism. He describes the Negro in this damming stance:

I am apt to suspect the Negroes to be naturally inferior to the whites. There scarcely ever was a civilized nation 
of that complexion, nor even any individual eminent either in action or speculation. No ingenious manufactures among them, no arts, no sciences. On the other hand, the most rude and barbarous of the whites, such as the ancient Germans, the present TARTARS, have still something eminent about them, in their valour, form of government, or some other particular. Such a uniform and constant difference could not happen, in so many countries and ages, if nature had not made an original distinction between these breeds of men. Not to mention our colonies, these NEGRO slaves dispersed all over Europe, of whom non ever discovered any symptoms of ingenuity; though low people, without education; will start up amongst us and distinguish themselves in any profession. In JAMAICA, indeed, they talk of one Negro as a man of parts and learning; but it is likely he is admired for slender accomplishments like a parrot, who speaks a few words plainly ${ }^{9}$.

Max Weber was caught in this web of intellectual rascality when he averred that all forms of indices for civilization existed in Europe namely arts, music, architectures, printing, science, politics and other aspects of human endeavour. He asserts that it is only in Europe that science had reached its apogee of evolution which

...we recognize today as valid. Empirical knowledge, reflection on problems of the cosmos and of life, philosophical and theological wisdom of the most profound ... the full development of a systematic theology must be credited to Christianity under the influence of Hellenism. ${ }^{10 .}$

It is amazing that up till now Eurocentric ideas are still prevalent in Africa. The invention theory of Terrence Rangers is paradigmatic. In the face of the self recovery or the renaissance movement by some Africans, Rangers puts up a new theory. According to him, whatever is rediscovered and called African vis-avis civilization are inventions of Europe. Hence, there can never be 
any originality in African identity and culture. All these are at their best, the inventions of Europe especially as the name was invented.

This atmosphere has made it conducive for Europeans to subtly manipulate Africans to view the world from European perspectives in all spheres as social, political, developmental, technological, scientific etc. This mentality took sway as even African intellectuals began to reject and deny their own cultural and intellectual achievements. Nwala captures this: 'It was African scholars who were affected by Eurocentric education or who had not been exposed to the rich cultural history of Africa that denied the existence of African philosophy during the "Great Debate" of the seventies and eighties, 11

This Eurocentric notion pervades all aspects of life in Africa. Even the consumer behaviour tilts more towards European goods and services. This has engendered the alternative for African development to come from Europe. Expatriates are invited to design technologies, politics, economy etc. The Brentton Wood institutions have taken over subtly. Its latest strategy is globalization which has resulted in the near absence of medium economy as the West is draining the rest of the world. A pertinent question is, should African development toe the line of Eurocentrism bearing in mind the environmental dimension to development? All we have done so far is to highlight the meaning and impact of Eurocentrism. We shall take our position of what credible option should be taken subsequently. We now turn to Afrocentrism.

\section{Afrocentrism and African Development.}

We noted earlier that imperialism bequeathed Africa with two main unforgettable experiences namely the denial of African identity and the tendentious imposition of western thoughts and cultural realities and perspectives. African achievements of the Nubian culture were appropriated as European. Nwala notes:

African achievements in science and philosophy were appropriated as European achievements. Thus, we read about such African philosophers like St. Augustine, Origen, Philo, Plotinus, Porphyry, etc as part of Western intellectual tradition and achievement. The great achievements of Egyptian thought were largely 
appropriated as European achievements. This is a phenomenon which GGM James called Stolen Legacy ${ }^{12}$

Thus, it did not take long for European perspectives to triumph over those of Africans. Hence, what is today referred to as colonial mentality took sway and Africans took to denying and rejecting their intellectual and cultural prowess. Those who got trapped in Europe and America during the slave trade were consequently made to develop low self esteem. This consignment as vagabonds on the part of the African diaspora in the face of racial discrimination forced them to self emancipation. This flaming spirit of freedom and nationalism took two forms namely the struggle and subsequent freedom of Africa politically and the search for African identity in the pages of antique history.

A variety of intellectual materials emerged in the course of this search for identity. Among those pioneers of Afrocentric ideas are William Dubois, GGM James, Anta Diop and Martin Bernal. What then is Afrocentrism? This concept which means African centredness was created by Afro-American intellectuals in asserting that Africans should be given their intellectual pride of place as the originators of civilization. Gordiano Bruno accepts this intellectual debt: "We Greeks owe Egypt, the grand monarchy of letters and nobility to be the parents of our fables, metaphors and doctrines" 13

Onyewuenyi writes copiously the aims and objectives of the Afrocentric movement:

The Afrocentric movement is a series of activities by concerned African and African-American scholars and educators and directed towards achieving the particular end of ensuring that the African heritage and culture, its history and contribution to world civilization and scholarship are reflected in the curricula on every level of academic instruction.....Advocates of Afrocen-trism demand a reconstruction and rewriting of the whole panaroma of human history in its account of the origin of mankind, the origin of philosophy, science, medicine, agriculture architecture etc ${ }^{14}$ 
Radical Afrocentrism exists. Some critics as Arthur Schlesinger Jr. have dismissed it as superficial, romantic and shallow ideology. Asante, a radical Afrocentrist voiced his fulfillment: "African people for over 300 years have lived on the intellectual terms of Europeans. The African perspective has finally come to dinner" 15

Accordingly, he sees Eurocentrism as a complete dislocation, self-alienation, disorientation and misinformation of the Afro-Americans. It is evident however that the flaming spirit of freedom in Afrocentrism has led some to consider it as a racial ideology. Though our interest in this paper is to relate Afrocentrism and Eurocentrism to development and to indicate where Africa may follow for authentic development, we shall present Onyewnenyi's defense against alleged racialism of Afrocentrism. He asserts:

Afrocentrism, which means African centred-ness, does not violently confront any person or people, but is a resolute attempt to put the records right. It is about placing African people within their own historical framework. It is a demand that the contributions of Africans in all areas of civilization be reflected in world history ${ }^{16}$

We have tried to lay bare the concept of Afrocentrism. But how has it affected development in Africa? It should be noted that Eurocentric thought has led to the tendentious capturing of the African mind in all the spheres of development. As an ideology that arose as a reaction against Eurocentrism, Afrocentrism perceives authentic development as that, that should be grown and bred in Africa. It seems to advise Africans to boycott all the "boycottables" of Eurocentrism. This phrase captures lucidly the spirit of Afrocentrists. Even Keita feels that development in African could only be ensured when discourse itself is predominantly that of African theorist within the context of African environmentsUniversities and research centers. Thus seen, maximal preference for African agencies are ideal for progress in Africa. It is however, very disheartening that the Afrocentric visions are not shared by the leadership in Africa. Hence the presence of Eurocentric or Aryan model; what Mazrui termed the "Greek mystique" of development still persists Africa. 


\section{Whither Africa?}

Development is a holistic evaluation process of the epistemic, cultural, normative, psychological and sociological stance of a group of people. A strong overhaul will make for a stronger hold and technological indices that are seen in the modern times as the hallmarks of development. Africa has been raped and since then, it is not the same. In making for a rational choice for African development, it will be an exercise in self-conceit and deceit for any of the two opposing ideologies in discourse to ignore the other.

Our position is that since there is hardly any idea one can call unadulterated African given our historical background; and since Africans can hardly imbibe unadulterated Eurocentric ideas, there should be a multicultural approach. What then is multiculturalism? This is an attempt to place the child at the middle of the intellectual experience and not an attempt to replace all things either European or African. The New Webster's Dictionary of the English Language defines multiculturalism as "The emphasis in education on encouraging and understanding of and appreciation for the contribution and cultural identities of various groups in a society" 17

It is our view that since Africa is an ideologically polarized society, it will not augur well with the existential realities of our time to look into any of the schools above for authentic development model for Africa. This is especially as most of those radical opponents of Eurocentrism cannot extricate Eurocentric thoughts from themselves. Hilde Hein captures this mood in Onyewuenyi -a professed Afrocentrist: 'While I believe, sadly that Fr. Onyewuenyi is probably right in his accusations that the Egyptian origin of Greek philosophy have been viciously suppressed, I believe that he too, concedes more than he might (or should) to his own Western education'18 This mood is at times reflected by other scholars in a way that is depictive of inferiority complex; Areji's view is paradigmatic: 'Nevertheless, Afrocentricity is a worthwhile project. For a people, who have been long oppressed and subjected to subhuman conditions, for a race that was madean object of history rather than a subject of history.... ${ }^{19}$

However, why did Africa cave in to Eurocentric ideology? In his paper entitled "The Absence of a genuine supreme being in 
Traditional African Thought, Ethics and their Effect on contemporary African society" Agbakoba traces the answer to the above question to the particularistic traditional ethics of Africans as against the universalistic ethics of Europe. This in turn consigns African's with the lack of a universal secondary ideology that gives a people stern and firm hold on themselves. He like other scholars as Afigbo refused to push all the blames for the gross poverty in Africa to its stint with colonialism. We strongly share this view: Afigbo states:

Why is it that almost every major situation so far known in history appears to have placed the Blackman, his historians, sociologists and other cultural interpreters to invest him with responsibility for what happens to and around him. The central peg in which many scholars... have hung the blackman's history is ... "a race under perpetual siege"... it means he is "effect" rather than cause that he is an object on which things act rather than a subject that act on things ${ }^{20}$

The question now is how do Africans make themselves the subject of history rather than its object? Africa as a society with these two opposing ideologies should embolden itself with the challenge of appreciating the need for a multicultural realty. This entails that there is no problem with borrowing anything that is good in Eurocentrism especially in this period of globalization-the latest stage of imperialism. But all we are advocating is that before one gets to drive a bargain with another, such a one should increase his bargaining power so as to drive for an equal bargain. As it is now Eurocentrism is having the upper hand in the game of development in Africa. We should go insular and insulate ourselves with the secondary ideology that will eschew the particularistic and materialistic ethic that have affected our psyche (psychology) As it is today the quality and strength of the black man's reaction to Eurocentrism is theoretically not strong enough. We should develop a new pedagogy of development to include austerity, hard work, rationality, universality, objectivity and internalize them. This does not mean that we should throw away the values that we have but that we should adapt tradition with a new ideology that will take our 
experiences of the past 300 years into cognizance. This will predispose us with knowing what we want and being serious to say no to what we do not want.

\section{Conclusion}

The search for an authentic model for African development is by no means an easy one. This is more so when Eurocentric thoughts pervade the realm of governance in Africa with the few intellectuals in the academia pursing Afrocentric thoughts. This paper studied the meanings of the concepts of Eurocentrism and Afrocentrism and related them to African development. It equally took a diachronic view of development as the indices of development had faced evolution since the inception of civilization. At this juncture, it is imperative that we should not accept the view that Africa never developed, is undevelopable and ipso facto a special case for developmental studies. This is because history is replete with epochs when Africa called the shots in civilization.

It is after weighing the implications of an adulterated society where there is "syncretism" of ideologies that we opted for the development of virile secondary ideologies that should be internalized before going to bargain and exchange ideas with the west. No sane person will run away from anything that will benefit him, all he has to do is to position himself in such a way that he could exchange ideas by barter. I do not mean however that Africa should cease to communicate with the West for a while; all I mean is that in the process of developing, internalizing and disseminating his sacred values, she should guide against further erosion of her values for the forces of civilization can never allow anybody as it is today to be on his own. It is only intellectual rascality that can let one go insular when one could get external ideals that could soar up ones developmental capacities. How does this idea get internalized? The value of education can never be over-emphasized. Onyewuenyi notes :

The leaders of the movement are very much aware of the roles of education in character formation. They trace the root of Africa-American's feeling frustration, self alienation and inferiority to the education (miseducation) that the system has imposed on them-an 
education that has stuffed them with an overdose of western ideology and denied them of any knowledge of their own ancestral history and culture ${ }^{21}$.

Thus seen, there should be a total overhaul in the curriculum of education in Africa from Nursery to Tertiary levels to enable future Africans to learn how to drag a harder bargain. By this I mean to acquire a developmental status or position that is capable of placing Africa on an equal round table with other developed continents of the world. 


\section{References}

1. Martin Khor, Globalization and the South, Some Critical Issues (Ibadan: Spectrum books Ltd 2001) p.i.

2. Akin L. Mabogunge, The Development Process: A Spatial Perspective (London: Hudtchinson and co ltd 1980) p.45

3. J.C.A. Agbakoba," A Critical Examination of the Concept of Development and Development Philosophy in Relation to Africa". Unpublished Nsukka 2005 p.2

4. E.M Rogers Modernization Among Peasants (Newyork Holt Rinehart and Winston Inc. 1969) pp.8-9

5. Lausana Keita, "Introduction to Philosophy and Development" African development, Vol. XXIX No1, 2004 p. 2-3.

6. I bid p..5

7. Hugh Trevor-Roper, The Rise of Christian Europe (London: Jarrold and Sons ltd reprinted ED. 1967) p.9

8. G.W.F. Hegel Philosophy of History (New York, Willey Books 1964) p.9

9. David Hume, Essays on National Characters (Middle sex: Penguin books 1969) p. 208

10. Max Weber, The Protestant Ethic and the Spirit of Capitalism (New York: Charles Scribners and Sons 1958) p.13

11. T. U. Nwala, Critical Review of the Great Debate on African Philosophy (1970-1990) (Nsukka: William Amo Centre for African Philosophy UNN 1992) p.5

12. T. U. Nwala "Critical Examination of the Background of Contemporary African Thought"; Lecture presented under the auspices of the University of Oxford African Society, at St Anthony's College, University of Oxford April 27 $7^{\text {th }}$ 1993. p. 1

13. Giordiano Bruno cited in Martin Bernal Black Anthena: The AfroAsiatic Roots of Classical Civilization Vol. I (London: Free Association Books 1987) p.152

14. I.C. Onyewuenyi, The African Origin of Greek Philosophy, An Exercise in Afrocentrism (Nsukka: University of Nigeria Press ltd 1993) p.39-40

15. Molefi Asante, "Putting Africa at the Center" Newsweek (23 ${ }^{\text {rd }}$ September 1991) p.42

16. Onyewuenyi Loc cit p.21

17. Lawrence T Loriner etal ed. The New Webster's Dictionary of the English Language Int'l edition (New York: Lexicon Guild Group. 1995) p 656

18. Onyewuenyi Loc cit p.vii 
19. A.C. Areji, "Eurocenticity Afrocentricity and Globalization" in Uche Vol. 112005 p. 65

20. A.E Afigbo, " History and Responsibility" A key note Address delivered at the meeting of American studies Association of Nigeria held at the University of Nigeria Nsukka on $24^{\text {th }}$ February 1993) p.11

21. Onyewuenyi Loc cit p. 39 